\title{
Migration of labeled bone marrow MSCs and skin fibroblasts after systemic and local transplantation in rat burn wound model
}

\author{
E. A. Shchegelskaya ${ }^{2}$, T. G. Grigorieva ${ }^{1}$, E. A. Omelchenko', \\ A. S. Zabirnyk ${ }^{1}$, E. V. Markelova ${ }^{1}$, S. G. Panibrattseva ${ }^{1}$, I. A. Borovoy ${ }^{3}$, \\ G. I. Gubina-Vaculik ${ }^{2}$, G. A. Oleynik ${ }^{1}$ \\ ${ }^{1}$ Kharkiv Medical Academy of Postgraduate Education \\ 58, Korchagintsev Str, Kharkiv, Ukraine, 61176 \\ ${ }^{2}$ Kharkiv National Medical University \\ 4, Lenina ave., Kharkiv, Ukraine, 61022 \\ ${ }^{3}$ Institute for Scintillation Materials, NAS of Ukraine \\ 60, Lenina ave., Kharkiv, Ukraine, 61001 \\ shcheglik2@gmail.com
}

\begin{abstract}
Aim. To study migration of syngeneic bone marrow MSCs and skin fibroblasts (FB), labeled by fluorochromes, after intravenous (IV) and local transplantation in a rat burn wound model (BWM). Methods. Rats were divided into 3 groups: C - without burn + IV injection of labeled MSCs and FBs mixture; O1 - BWM + IV injection of labeled MSCs and FBs mixture; O2 - BWM + fibrin matrix filled with labeled cell mixture. MSCs were labeled by green fluorochrome, and fibroblasts - by red one. The presence of labeled cells in cryocuts of the skin, liver, kidney and bone marrow was assessed on the 3 and 7 days after transplantation. Results. Skin FBs selective migration to the regenerating burn wound and MSCs accumulation in the kidneys were found in rats of group $\mathrm{O} 1$ on day 7 after the IV injection. The labeled cells proliferated in the transplanted fibrin matrix and participated in the wound regeneration. MSCs partly migrated to the bone marrow after the IV injections. Conclusions. IV transplanted syngeneic bone marrow MSCs and skin FBs (passage 0) migrate to the burn wound and participate in the healing. Migration of bone marrow MSCs in the kidneys can prevent kidney failure after burn.
\end{abstract}

Ke y w o r d s: burn wound, migration, fibroblasts, MSCs, fluorochrome, transplantation.

\section{Introduction}

The transplantation of skin fibroblasts (FB) and bone marrow mesenchymal stem cells (BM MSCs) is successfully used in the treatment of deep and extensive burns in many modern burn centers of the world. The beneficial effect of fibroblasts on the process of healing burn wounds was proven 20 years ago, when transplantations of both auto- and allofibroblasts on different matrices were found to be efficient [1]. BM MSCs became a promising can- didate for application in the regenerating medicine due to their pluripotency. During the treatment of the wounds, MSCs are transplanted into the latter via injections or using biodegradable matrices, based on collagen, fibrin, gelatin, chitosan, and hyaluronic acid [2]. The positive effect of BM MSCs in regenerating skin at different stages of wound healing was proven both in the experiments on animals and in the series of clinical trials, and it was established that the injury stimulates the acceptance of MSCs by skin and induces their differentiation

(C) 2015 E. A. Shchegelskaya et al.; Published by the Institute of Molecular Biology and Genetics, NAS of Ukraine on behalf of Biopolymers and Cell. This is an Open Access article distributed under the terms of the Creative Commons Attribution License (http://creativecommons.org/licenses/by/4.0/), which permits unrestricted reuse, distribution, and reproduction in any medium, provided the original work is properly cited 
into skin cells [3]. One of possible mechanisms of healing skin wounds is MSCs differentiation into fibroblasts in the injured zone and their synthesis of extracellular matrix proteins.

The comparative evaluation of the efficiency of transplanting embryonic fibroblasts and bone marrow MSCs in the treatment of deep burns in rats demonstrated that the transplantation of these cells on the surface of the wound decreases its cellular infiltration, accelerates the formation of new vessels and granulation tissue. Moreover, the MSCs transplantation leads to a higher regeneration rate compared to the transplantation of embryonic fibroblasts [4]. The most efficient method of treating burn wounds is a complex approach, which simulates normal skin structure and promotes its faster and more normal formation. For instance, it was previously demonstrated by us that the use of biodegradable fibrin films, covered with BM MSCs or FBs culture for the treatment of wound surface of the burn model in combination with xenoskin and autokeratinocytes leads to the formation of the dermal type regenerate and the 2-5-fold acceleration of wound healing compared to the control [5].

There is still an unresolved issue of the efficiency of IV application of BM MSCs and especially skin FBs in the burn wound treatment and burn disease in general, which is usually characterized by multiple organ failure. One of the studies, comparing local and systemic injections of cultivated dermal pluripotent cells to rats with wounds in combination with radiation injury or without one, demonstrated that with local injection the effect was observed sooner, but only systemic transplantation of cells had impact on healing the wounds of radiation-exposed rats. As the radiation damaged bone marrow (MSCs reserve), externally introduced stromal cells took an active part in the wound regeneration [6]. It is known that the MSCs cultures of different passages and origin are heterogeneous populations of cells, different in their ability to migrate to one or another zone of damage or inflammation. To study the mechanisms of cell migration, MSCs are transfected with the genes of fluorescent proteins or the cells are stained with vital fluorochromes. These data are used to elaborate the methods of targeted migration of MSCs into a specific niche in the organism [7].

The study of the migration ways of MSCs and skin FB, stained with fluorescent dyes, at their systemic and local transplantation to rats with wound models, may clarify the role of these cells in wound regeneration.

The aim of this work was to study the migration of BM MSCs and skin FB, labeled with green and red vital fluorochromes respectively, after their intravenous (IV) and local syngeneic transplantation in the fibrin matrix to rats with burn wound model (BWM).

\section{Materials and Methods}

The study was conducted on 18 female rats of Wistar line, with the weight of 250-300 g, which were used to simulate a deep burn wound of $20 \%$ area in conditions of thiopental-induced anesthesia. After local removal of skin hair on the back of the animals, the latter were inflicted a contact burn using a round tip of the electric soldering iron with the diameter of $4 \mathrm{~cm}$. Primary necrectomy was performed on all the experimental animals $24 \mathrm{~h}$ later.

The rats were divided into three groups of 6 animals: C - no burn + IV injection of labeled MSCs and FB; O1 - BWM + IV injection of labeled MSCs and $\mathrm{FB} ; \mathrm{O} 2-\mathrm{BWM}+$ fibrin matrix with the mixture of labeled MSCs and FBs + xenoskin. Acellular pig skin (Kombustiolog Company, Ternopil) was used as xenoskin.

The localization of labeled cells in skin, liver, kidneys and bone marrow of rats was studied on days 3 and 7 after the transplantation.

The experiments were conducted in the vivarium of the Kharkiv Medical Academy of Postgraduate Education in accordance with the international requirements of the European Convention for the Protection of Vertebrate Animals (Strasbourg, 1985) and General principles of conducting experiments on animals (Kyiv, 2004). All the manipulations with animals, including decapitation, were performed using thiopental anesthesia. 
Migration of labeled bone marrow MSCs and skin fibroblasts after systemic and local transplantation in rat burn wound model

The methods of preparing the cultures of MSCs and skin FBs and their labeling with fluorescent dyes

The methods, described by us previously [5], were used to obtain primary cultures (passage 0 ) of bone marrow MSCs and skin fibroblasts of rats. The reagents, sera and media of SIGMA-ALDRICH company (USA), and the culture dishes of PAA company (Austria) were used in the work.

The fluorescent dyes DIO C18 (3,3'-dioctadecyloxacarbocyanine bromide, C53H85BrN2O2, FW 863,16) and Rhod Chol (cholesterol ester of rhodamine C, C55H75CIN2O3, FW 847,65), synthesized in the Institute of Scintillation Materials, NASU, have low solubility in water and, due to their hydrophobic property, are easily bound to lipid areas of membrane structures of the cells. This property allows using them as intravital fluorescent markers for different types of cells.

The fluorescence maximum for DIO C18 with the excitation in the range of $455-490 \mathrm{~nm}$ is $515 \mathrm{~nm}$ (green fluorescence). The dye Rhod_Chol is remarkable for red fluorescence (maximum $580 \mathrm{~nm}$ ) at the excitation of $490 \mathrm{~nm}$.

These dyes are closely bound to the membrane structures of cell cytoplasm, do not penetrate the nucleus, are resistant to discoloration and well-kept in the cells, are not cytotoxic in optimal conditions of dying.

The stock solutions of fluorochromes DiO C18 $(\lambda \mathrm{em}=515 \mathrm{~nm}$, green) and Rhod Chol $(\lambda \mathrm{em}=580 \mathrm{~nm}$, red), prepared with $100 \%$ dimethylsulfoxide (DMSO, 10-3 M), were used to prepare their working solutions with saline solution (SS) and the final concentration of the dye in the solution was $2 \times 10$ $5 \mathrm{M}$. MSCs were labeled with green fluorochrome, and fibroblasts - with red one. For this reason the cell suspensions, obtained after the cultivation, were washed off fetal serum using centrifugation in Hanks' solution, then the pellet was resuspended in the working solutions of dyes (MSCs - in the solution DIO C18, FBs - in Rhod Chol solution). The cells were incubated in the dye solutions for $15 \mathrm{~min}$ at room temperature. Then the cells were washed in SS off the excess of fluorochrome by centrifugation at $430 \mathrm{~g}$ for $7 \mathrm{~min}$. The pellet was resuspended in SS and labeled MSCs and FBs were mixed in equal volumes (400 thousand MSCs/ml, 400 thousand FB/ $\mathrm{ml})$. The rats from groups $\mathrm{C}$ and $\mathrm{O} 1$ were given $\mathrm{IV}$ injections of $0.5 \mathrm{ml}$ of the mixture of labeled MSCs and FB. Some labeled cells from this mixture were plated in Petri dishes and cultivated for 3 and 7 days for the control of the dying quality and cell viability.

\section{The preparation of a fibrin matrix with cells}

Labeled MSCs and FBs were resuspended in Hanks' solution (200 thousand cells per $\mathrm{ml}$ ) and mixed with blood plasma, $0.3 \%$ calcium chloride was added to the mixture, the portions of $2 \mathrm{ml}$ were poured into each Petri dish $(\mathrm{d}=35 \mathrm{~mm})$ and incubated at $37^{\circ} \mathrm{C}$ for $15 \mathrm{~min}$ until fibrin gel was formed. In Experiment 2 the fibrin matrices with enclosed labeled fibroblasts (red) and MSCs (green) were transferred to the surface of burn wound and covered with acellular pig xenoskin to prevent wound drying.

\section{Histological methods of analysis}

The samples of skin, liver and kidneys with the size of $2 \mathrm{cc}$ were taken from rats on days 3 and 7 after the cell transplantation and transported on ice to the laboratory, where $20-25 \mu \mathrm{m}$ thick cryocuts were made using a freezing microtome MK-25 (Russia). 10-15 cryocuts were placed on each slide. $100-120$ cuts were prepared from each organ. Bone marrow smears were made from the femur bone of all the animals. The presence and distribution of fluorescent cells on cryocuts of tissues and bone marrow smears were estimated using a luminescent microscope Axioscope 40 (Carl Zeiss, Germany) with the magnification of 100. Instudio program was used to register microphotographs.

\section{Statistical analysis}

The comparative estimation of the number of fluorescent red and green cells in the liver, kidneys and skin of rats involved the determination of the average number of labeled cells per one cut after they were counted in all the cryocuts of each organ. The data were presented as mean \pm standard deviation (SD). The statistical analysis was performed using Statsoft 
Statistica 8.0 (license No. STA862D175437Q); Student's t-criterion was used for comparison. The value of $\mathrm{P}<0.05$ was considered statistically reliable.

\section{Results and Discussion}

Fluorescent dyes DIO C18 (green) and Rhod Chol (red) were previously used to study the migration of BM MSCs to treat Parkinson-like syndrome in rats [8]. This study also demonstrated the MSCs affinity to the zone of chemical destruction of brain in case of the intravenous injection. The same fluorochromes were used here to study the migration of primary cultures of skin FB, labeled red, and BM MSCs, labeled with green fluorochrome, in the organism of rats with a burn wound model after a single intravenous injection.

It was established that labeled FBs and MSCs in the mixed culture preserve their normal fibroblastlike phenotype and proliferate actively; the cell cytoplasm manifests green fluorescence of MSCs and red one - of fibroblasts (Fig. 1). Fibroblasts divide more actively, therefore, 7 days later they are much more numerous in the culture compared to MSCs.

The analysis of cryopreparations demonstrated that single MSCs and FBs (2 cells per 6-8 cuts) were found in all the studied organs of rats in group C (IV injection of the mixture of MSCs and FBs to rats without any burn) in different periods after the transplantation. In the bone marrow only single MSCs (3-4 cells per smear) were found, and none FBs.

On day 7 after the IV injection of the cell mixture, group $\mathrm{O} 1$ demonstrated a considerable (10-fold) increase in the number of green MSCs in the kidneys compared to the control (3-5 cells per each cut on average) (Fig. $3 \mathrm{~B}$ ) and a simultaneous multiple increase in the number of red FBs in the burn wound area (8-12 cells per each cut) (Fig. $3 A$ ), compared to the control and 3 days after the cell injection. A considerable increase in the number of green MSCs (2-3 per each cut), compared to the control and day 3 after IV injection in O1, was also found on the cuts of the wound (Fig. $4 A, B$ ). Single green MSCs were found in the liver and bone marrow of animals of this group on days 3 and 7 of the studies. Fibroblasts on the cuts of kidneys and liver were observed very rarely.
The zone of inflammation in the area of spontaneously healing burn wound is likely to produce specific factors which lead to the selective migration of skin FBs into this target at their systemic injection. BM MSCs also migrate into the same injured zone, but in a smaller amount. Contrary to fibroblasts, a part of MSCs also migrate into the liver, kidneys and bone marrow, which may be explained by the fact that they are less differentiated cells, expressing a wide spectrum of receptors, and may participate in the regeneration of these organs and tissues, which undergo a toxic burden due to the development of a burn disease.

As for the animals from group O2, red (FB) and green (MSCs) fluorescent cells were found on days 3 (Fig. $5 A$ ) and 7 of the studies in the area of wound surface, which was covered with a fibrin matrix with enclosed labeled MSCs and FB. Moreover, on day 7 there were more labeled cells in the regeneration zone than on day 3, which may testify to FBs and MSCs entering the phase of active division. Similar to the cells culture, FBs in the regenerating wound divided more actively, therefore, they were 3-4 times more abundant on the cuts compared to MSCs (Fig. $5 B$ ). On day 7 it was evident by the morphological parameters that the wound healing in group $\mathrm{O} 2$ was faster and of a higher quality than in $\mathrm{O} 1$. Neither red (FB) nor green (MSCs) fluorescent cells were found in the liver, kidneys and bone marrow of these animals during the period of analysis. Therefore, these cells cannot migrate into the mentioned organs with this type of transplantation during this period. Being enclosed into the fibrin matrix, they have direct contact with the wound and take an active part in the regenerating processes of its healing.

Single green MSCs in the amount of 5-10 cells per smear were found in the preparations while studying the bone marrow smears of the animals from groups $\mathrm{C}$ and $\mathrm{O} 1$ (Fig. $6 A, B$ ). Fibroblasts were not found in the bone marrow of rats after the IV injection. There were no reliable differences in the amount of MSCs in bone marrow of control and experiment animals. Thus, the phenomenon of cell homing was confirmed for IV transplantation of BM MSCs. Similar migration of MSCs into the bone 


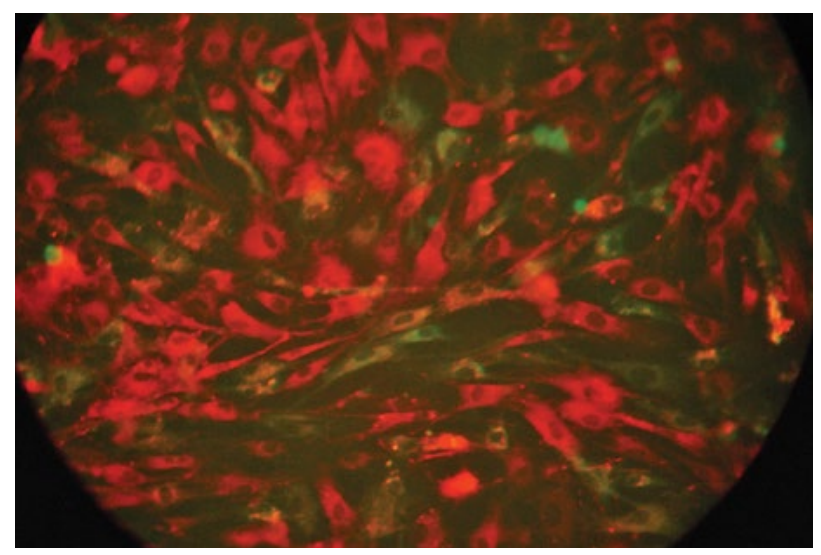

Fig. 1. A mixed culture of labeled FBs (red) and MSCs (green) on day 7 of in vitro cultivation. Luminescent microscopy. $\mathrm{x} 200$. marrow, lungs and tumor was demonstrated for systemic and local introduction of MSCs of adipose tissue, labeled with fluorescent red protein TurboFP635 [9]. MSCs express many receptors and molecules of cell adhesion, which promote the migration into the bone marrow and the target tissue. Nonetheless, precise mechanisms of MSCs homing have not been elucidated completely [10]. Single red fluorescent cells were found on the cryocuts of intact animals skin after IV injection of fibroblasts. In this case we may assume the homing of skin fibroblasts, which has been studied even less than MSCs homing. Notably, the data, obtained by us, refer to the speci-

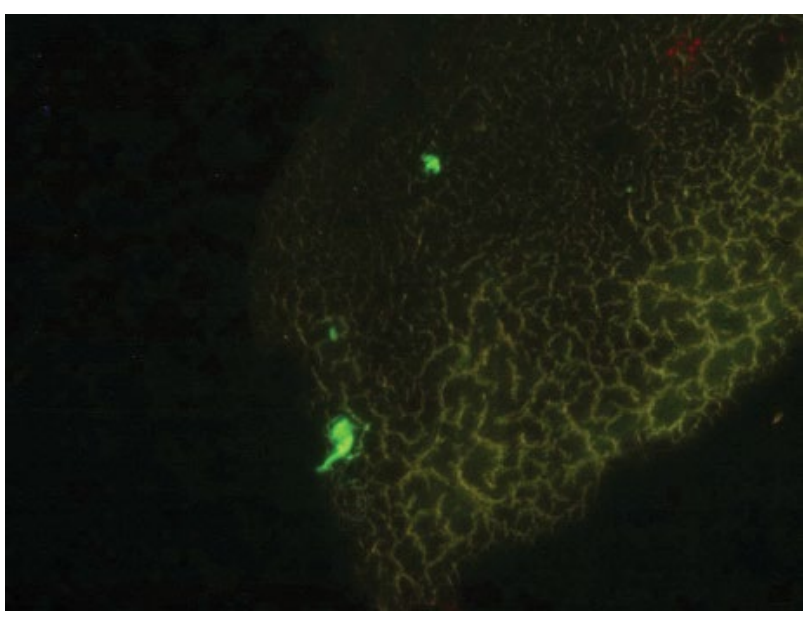

A

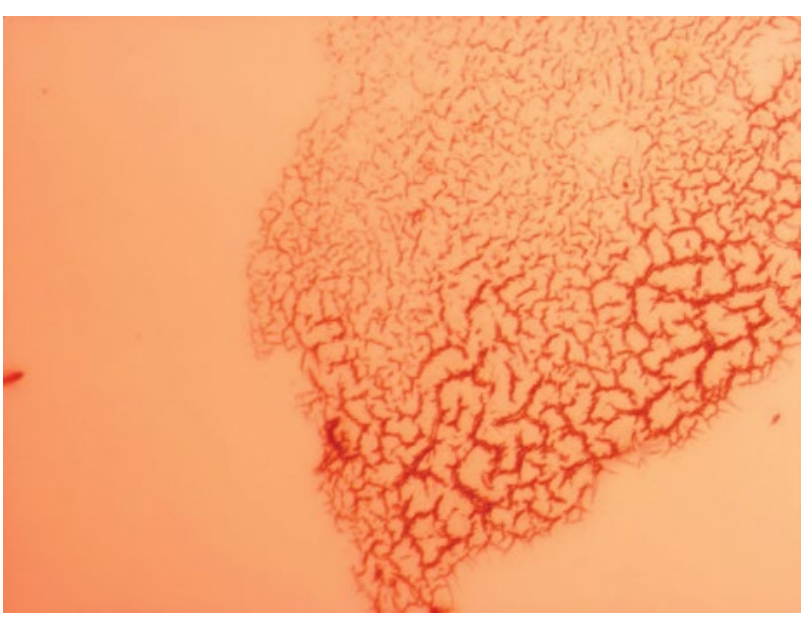

$B$

Fig. 2. BM MSCs, labeled with DIO C18 (green), on the cryocut of kidney of the rat from group O1 on day 7 after IV injection of the labeled cell mixture. $A$ - luminescent, $B$ - light microscopy. x 100 .
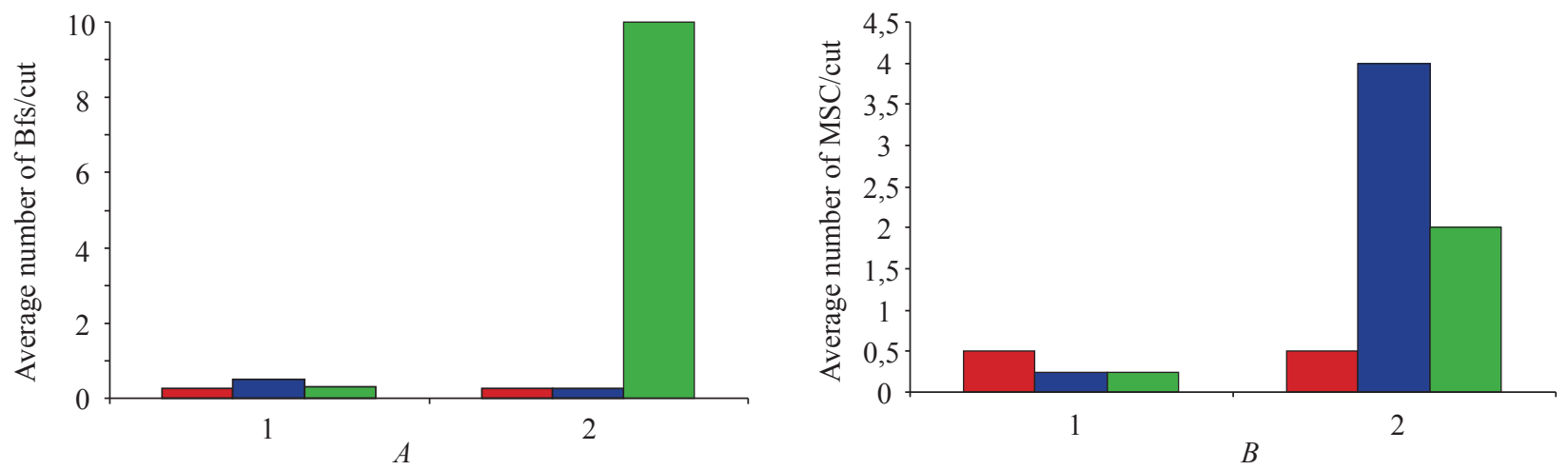

Fig. 3. A number of labeled FBs $(A)$ and MSCs $(B)$ in the tissues of liver, kidneys, and skin of rats on day 7 after IV injection of the labeled FBs and MSCs mixture. 1 - Control, 2 - Experiment 1; $\square$ - liver, $\square$ - kidney, $\square$ - skin 


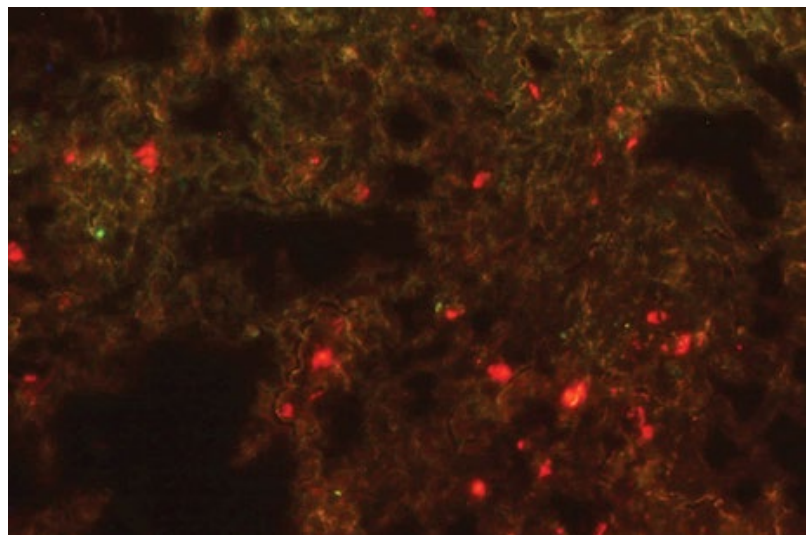

A

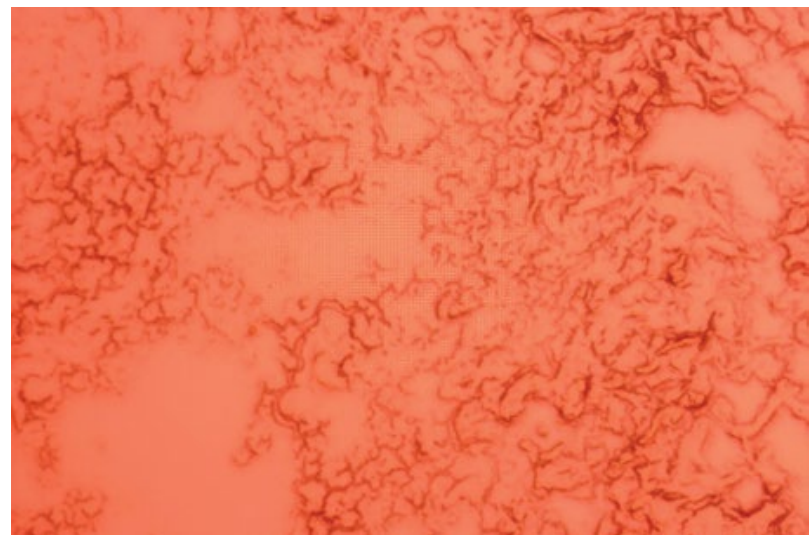

B

Fig. 4. Labeled FBs (red) and MSCs (green) on the cryocuts of the regenerating skin from the burn wound on day 7 after IV injection of labeled cells. $A$ - luminescent, $B$ - light microscopy. x 100 .

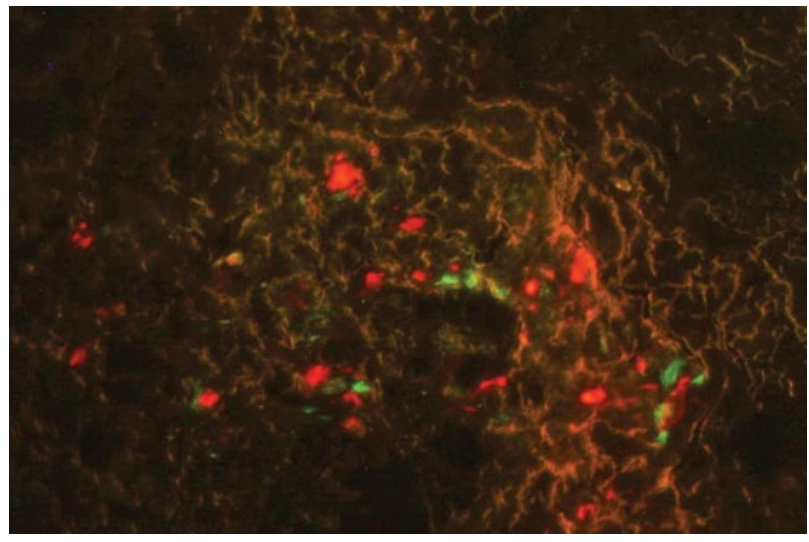

A

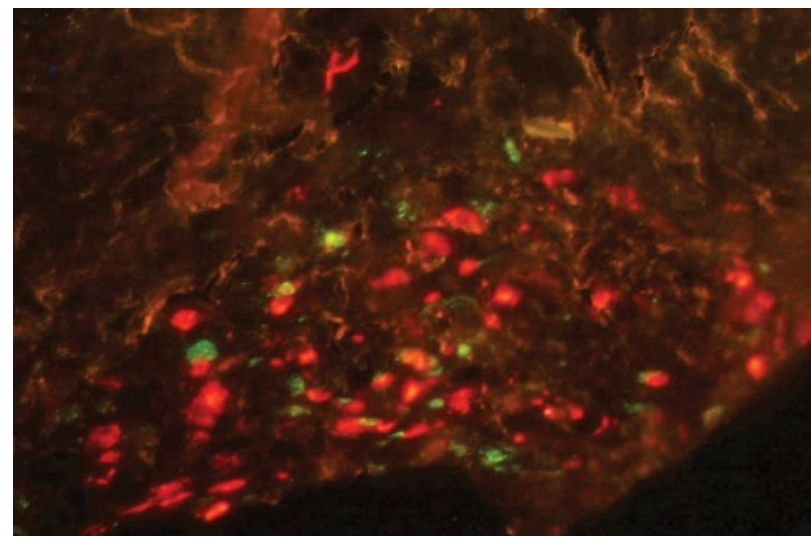

B

Fig. 5. Labeled FBs (red) and BM MSCs (green) on days 3 (A) and 7 (B) of the fibrin matrix transplantation into the wound on the cut of skin of the regenerating wound of group $\mathrm{O} 2$ rats. Luminescent microscopy. $\mathrm{x} 100$.

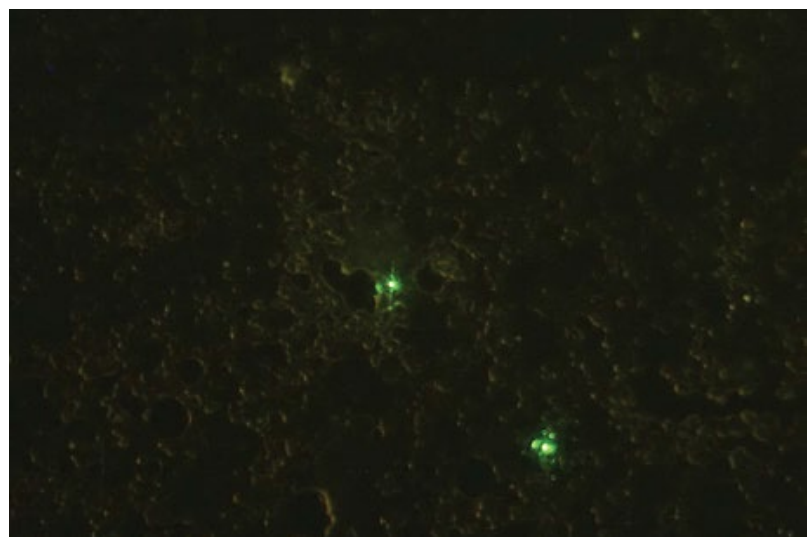

A

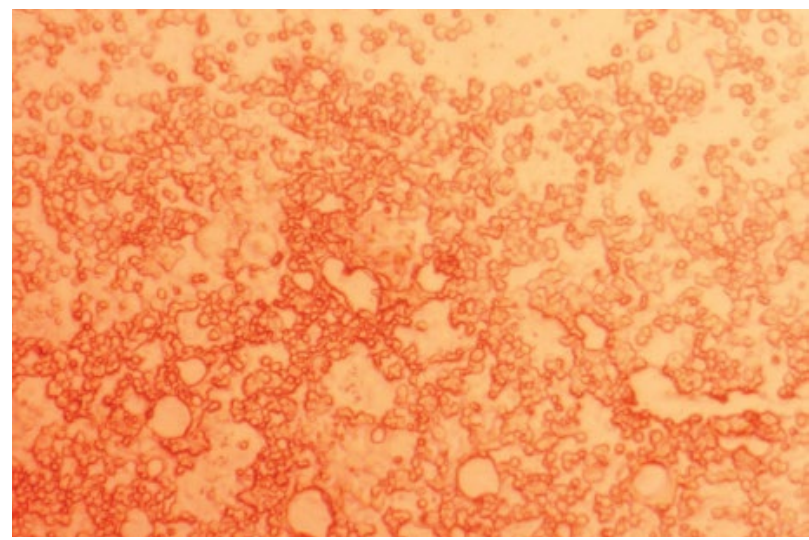

B

Fig. 6. BM MSCs, labeled with green fluorochrome in the smear of rat bone marrow from O1 on day 7 after IV injection of the labeled cell mixture. $A$ - luminescent, $B$ - light microscopy. x 100 . 
ficities of cell migration of FB and BM MSC primary cultures at syngeneic transplantation. It is known that after multiple subcultivations or cryopreservation MSCs and FBs may change the spectrum of expressed receptors and cytokines, and thus their migration preferences may be different. The application of allogeneic or xenogenic cell cultures while studying the migration of these cells may also have some specificities [11, 12].

The method of intravital staining of cells with fluorochromes allows studying the ways of migration of labeled cells (especially early passages) in the organism of animals in short terms (up to 2 weeks) after the injection. The disadvantage of this method is the fact that after the cell division the labeled membrane structures are distributed among daughter cells and the fluorescence gradually weakens. Cell lines or MSC cultures, transfected with the genes of fluorescent proteins, such as GFP, are more suitable for long-term studies of cell migration [13].

The data, obtained by us, may be used for the development of an optimal method of the cell therapy while treating extensive and deep burn wounds. For instance, both local transplantation of fibroblasts and bone marrow MSCs and their IV injection may be used for wound treatment. Systemic transplantation of MSCs may be especially efficient in treating the burn disease, because on day 7 after the burn they migrate into kidneys which carry a considerable burden in case of the extensive and deep burns.

\section{Conclusions}

1. The selective migration of skin FBs into the area of spontaneously regenerating burn wound and the accumulation of BM MSCs in the kidneys of these animals were found on day 7 after IV injection of the mixture of syngeneic labeled MSCs and FB.

2. The labeled cells (MSCs and FB) proliferate and participate in the process of wound healing in the fibrin matrix, transplanted onto the wound, moreover, FBs divide faster than MSCs.

3. Regardless of the wound, the IV injected syngeneic BM MSCs migrate into their niche - bone marrow. In similar conditions FBs do not migrate to the bone marrow.

4. Simultaneous systemic transplantation of primary cultures of BM MSCs and skin FBs may be efficient for healing the burn wounds and prevention of the burn disease.

\section{REFERENCES}

1. Sarkisov DS, Alekseev AA, Glushchenko, EV. et al. [Theoretical and practical aspects of cultured fibroblasts used for the skin integrity restoration]. Vestn Ross Akad Med Nauk. 1994; 6: 6-11.

2. Papuga AYe, Lukash LL. Different types of biotechnological wound coverages created with the application of alive human cells. Biopolym Cell. 2015; 31(2):83-96.

3. Kirby GT, Mills SJ, Cowin AJ, Smith LE. Stem cells for cutaneous wound healing. Biomed Res Int. 2015;2015:285869.

4. Shumakov VI, Onishchenko NA, Rasulov MF, Krasheninnikov ME, Zaidenov VA. Mesenchymal bone marrow stem cells more effectively stimulate regeneration of deep burn wounds than embryonic fibroblasts. Bull Exp Biol Med. 2003;136(2):192-5.

5. Markelova EV, Grigorieva TG, Shchegelskaya EA, Klymenko $V V$. [Bone marrow mesenchymal stem cells, fibroblasts and autokeratinocytes for burn wounds treatment in rats]. Experimentalna i Klinichna Meditsina. 2012; 54(1):30-5.

6. Chunmeng S, Tianmin C, Yongping $S$, Xinze R, Yue $M$, Jifu $Q$, Shufen L, Hui X, Chengji L. Effects of dermal multipotent cell transplantation on skin wound healing. J Surg Res. 2004;121(1):13-9.

7. Maijenburg $M W$, van der Schoot CE, Voermans $C$. Mesenchymal stromal cell migration: possibilities to improve cellular therapy. Stem Cells Dev. 2012;21(1):19-29.

8. Pyatikop VA, Msallam MA, Shchegelskaya EA, Kutovoy IA, Gubina-Vakulik GI. [Migration features of labeled bone marrow mesenchymal stem cells transplanted in rats with Parkinson-like syndrome].Ukrainian Neurosurgeon Journal. 2014; 3: 42-48.

9. Meleshina AV, Cherkasova EI, Sergeeva EA, Kleshnin MS, Turchin IV, Kiseleva EV, Dashinimaev EV, Shirmanova MV, Lukyanov SA, Zagaynova EV. The study of the interaction of mesenchymal stem cells and the tumor using the methods of fluorescent bioimaging. Sovrem Tekhnologii Med. 2012; 4: 7-16.

10. Sohni A, Verfaillie CM. Mesenchymal stem cells migration homing and tracking. Stem Cells Int. 2013;2013:130763.

11. Kholodenko IV, Konieva AA, Kholodenko RV, Yarygin KN. Molecular mechanisms of migration and homing of intravenously transplanted mesenchymal stem cells. J Regen Med Tissue Eng. 2013; 2:4. 
12. Augello A, Kurth TB, De Bari C. Mesenchymal stem cells: a perspective from in vitro cultures to in vivo migration and niches. Eur Cell Mater. 2010;20:121-33.

13. Li ZH, Liao W, Cui XL, Zhao Q, Liu M, Chen YH, Liu TS, Liu NL, Wang F, Yi Y, Shao NS. Intravenous transplantation of allogeneic bone marrow mesenchymal stem cells and its directional migration to the necrotic femoral head. Int J Med Sci. 2011;8(1):74-83.

Міграція мічених МСК кісткового мозку і фібробластів шкіри після їх системної та місцевої трансплантації у щурів з моделлю післяопікової рани

О. А. Щегельська, Т. Г. Григор'єва, О. А. Омельченко, А. С. Забірник, О. В. Маркелова, С. Г. Панібратцева, I. А. Боровий, Г. І. Губіна-Вакулик, Г. А. Олійник

Мета. Вивчення міграції сингенних МСК кісткового мозку і фібробластів (ФБ) шкіри, мічених флюорохромами, після внутрішньовенної (ВВ) та локальної трансплантації у щурів з моделлю післяопікової рани (МПР). Методи. Щури були розділені на 3 групи: $\mathrm{K}$ - без опіку + ВВ введення мічених МСК і ФБ; О1 - МПР + ВВ мічених МСК і ФБ; О2 - МПР + фібринова матриця з сумішшю мічених МСК і ФБ. МСК фарбували зеленим флюорохромом, а фібробласти - червоним. Розподіл мічених клітин на кріозрізах шкіри, печінки, нирок і кісткового мозку щурів вивчали на 3 і 7 добу після трансплантації. Результати. Виявлена вибіркова міграція ФБ шкіри в післяопікову рану і накопичення МСК КМ в нирках тварин групи О1 на 7 добу після ВВ введення мічених МСК і ФБ. У трансплантованій на рану фібриновій матриці мічені клітини проліферували та брали участь у процесі регенерації рани. При ВВ введенні МСК КМ спостерігалася їх міграція в кістковий мозок. Висновки. Системно введені сингенні МСК КМ і ФБ шкіри (0 пасаж) мігрують в зону післяопікової рани і беруть участь в її загоєнні. Міграція МСК КМ в нирки може попередити ниркову недостатність, що розвивається після опіку.
Кл юч о в і с л о в а: післяопікова рана, міграція, фібробласти, МСК, флюорохроми, трансплантація.

\section{Миграция меченых МСК костного мозга и фибробластов кожи после их системной и местной трансплантации у крыс с моделью послеожоговой раны}

Е. А. Щегельская, Т. Г. Григорьева, Е. А. Омельченко, А. С. Забирник, Е. В. Маркелова, С. Г. Панибратцева, И. А. Боровой, Г. И. Губина-Вакулик, Г. А. Олейник

Цель. Изучение миграции сингенных МСК костного мозга и фибробластов (ФБ) кожи, меченых флюорохромами, после их внутривенной (BB) и локальной трансплантации крысам с моделью послеожоговой раны (МПР). Методы. Крыс разделили на 3 группы: К - без ожога + ВВ введение смеси меченых МСК и ФБ; О1 - МПР + ВВ введение смеси меченых МСК и ФБ; $\mathrm{O} 2$ - МПР + фибриновая матрица с мечеными МСК и ФБ. МСК метили зеленым флюорохромом, фибробласты - красным. Наличие меченых клеток в коже, печени, почках и костном мозге крыс оценивали на 3 и 7 сутки после трансплантации на криосрезах и мазках. Результаты. Обнаружена избирательная миграция ФБ кожи в зону раны и накопление МСК КМ в почках крыс группы О1 на 7 сутки после ВВ введения меченых МСК и ФБ. В трансплантированной на рану фибриновой матрице меченые клетки активно делились и участвовали в ее регенерации. При ВВ введении МСК КМ частично мигрировали в костный мозг. Выводы. Системно трансплантированные сингенные МСК КМ и ФБ кожи 0 пассажа мигрируют в зону послеожоговой раны и участвуют в ее заживлении. Миграция МСК КМ в почки может предупредить вызванную ожогом почечную недостаточность.

Кл юче в ы е сл ов а: ожоговая рана, миграция, фибробласты, МСК, флюорохромы, трансплантация.

Received 28.07.2015 